\title{
Natural hazards in Santo Domingo de Heredia, Costa Rica, Central America
}

\author{
Jonnathan Reyes ${ }^{1}$, Mario Fernández ${ }^{2,3,4,5^{*}}$, Sara Grineski ${ }^{6}$, Timothy Collins $^{6}$ \\ ${ }^{1}$ School of Geography, University of Costa Rica (UCR), San José, Costa Rica \\ ${ }^{2}$ Preventec University of Costa Rica, San José, Costa Rica; *Corresponding Author: mario.fernandezarce@ucr.ac.cr \\ ${ }^{3}$ School of Geology, University of Costa Rica, San José, Costa Rica \\ ${ }^{4}$ Center for Research in Geological Sciences, University of Costa Rica, San José, Costa Rica \\ ${ }^{5}$ Red Sismológica Nacional (RSN: ICE-UCR), San José, Costa Rica \\ ${ }^{6}$ Department of Sociology and Anthropology, University of Texas, El Paso, USA
}

Received 1 November 2013; revised 1 December 2013; accepted 8 December 2013

Copyright (C) 2014 Jonnathan Reyes et al. This is an open access article distributed under the Creative Commons Attribution License, which permits unrestricted use, distribution, and reproduction in any medium, provided the original work is properly cited. In accordance of the Creative Commons Attribution License all Copyrights (C) 2014 are reserved for SCIRP and the owner of the intellectual property Jonnathan Reyes et al. All Copyright (C) 2014 are guarded by law and by SCIRP as a guardian.

\section{ABSTRACT}

Santo Domingo de Heredia, Costa Rica is a county facing serious risks from natural hazards, specifically flooding, earthquakes, volcanic activity and landslides. In order to inform disaster risk reduction efforts and improve the safety and well-being of local residents, this article assessed these natural hazards using a geographical approach. First, we described the four hazards based on a review of reports from previous emergencies, scientific papers and newspaper articles. Second, we integrated spatial data on each hazard to create a hazard density index for the county at the level of the census unit $(n=140)$. Results demonstrate that river flooding has caused the most damage of the four hazards in recent times. Both seismic and volcanic risks (specifically ash fall from volcanic eruptions) affect the entire area of Santo Domingo. Landslides have affected localized, settled areas of steep river canyons in the southern part of the county. In general, the highest density of hazards is located in the southern reaches of Santo Domingo. As such, we recommend that local authorities concentrate their management efforts in that area.

\section{KEYWORDS}

Hazards; Earthquakes; Floods; Eruptions; Landslides; Faults; Index

\section{INTRODUCTION}

The county of Santo Domingo de Heredia (Costa Rica,
Central America) has been impacted by natural hazards, such as floods, volcanic activity, landslides, and to a lesser extent by earthquakes, in the past. Santo Domingo is a 2484 square kilometer county (or canton) located in the province of Heredia, just north of Costa Rica's capital of San Jose, with approximately 37,000 people (Figure 1). We assessed and mapped flooding, volcanic, earthquake and landslide risks in order to aid in disaster risk management efforts in a region where little geographic information about these hazards was available. The lack of geographic information about hazards has inhibited planning and mitigation efforts in the region. This is in violation of Costa Rica's "National Law for Risk Prevention and Emergency Care", which requires everyone, starting with the State and ending with citizens, to participate in disaster risk management and that local authorities are responsible for disaster management in their territories.

\section{METHODOLOGY}

The study took place in two steps. First, we identified the four hazards and their past impacts based on a review of available information, which included reports from previous emergencies, scientific papers and newspaper articles. Second, we mapped the presence of each hazard in each census unit within Santo Domingo $(n=140)$ and used Arc View 3.3 to integrate all hazard layers in a global map of threats by creating a hazard density index [1]; the process is described in Figure 2. Geomorphological maps, derived from air photos, were used to evaluate areas at risk to landslides and flooding. To identify landslide risk, the Mora-Varhson-Mora method was used [2]. Volcanic and earthquake risk maps for Santo 


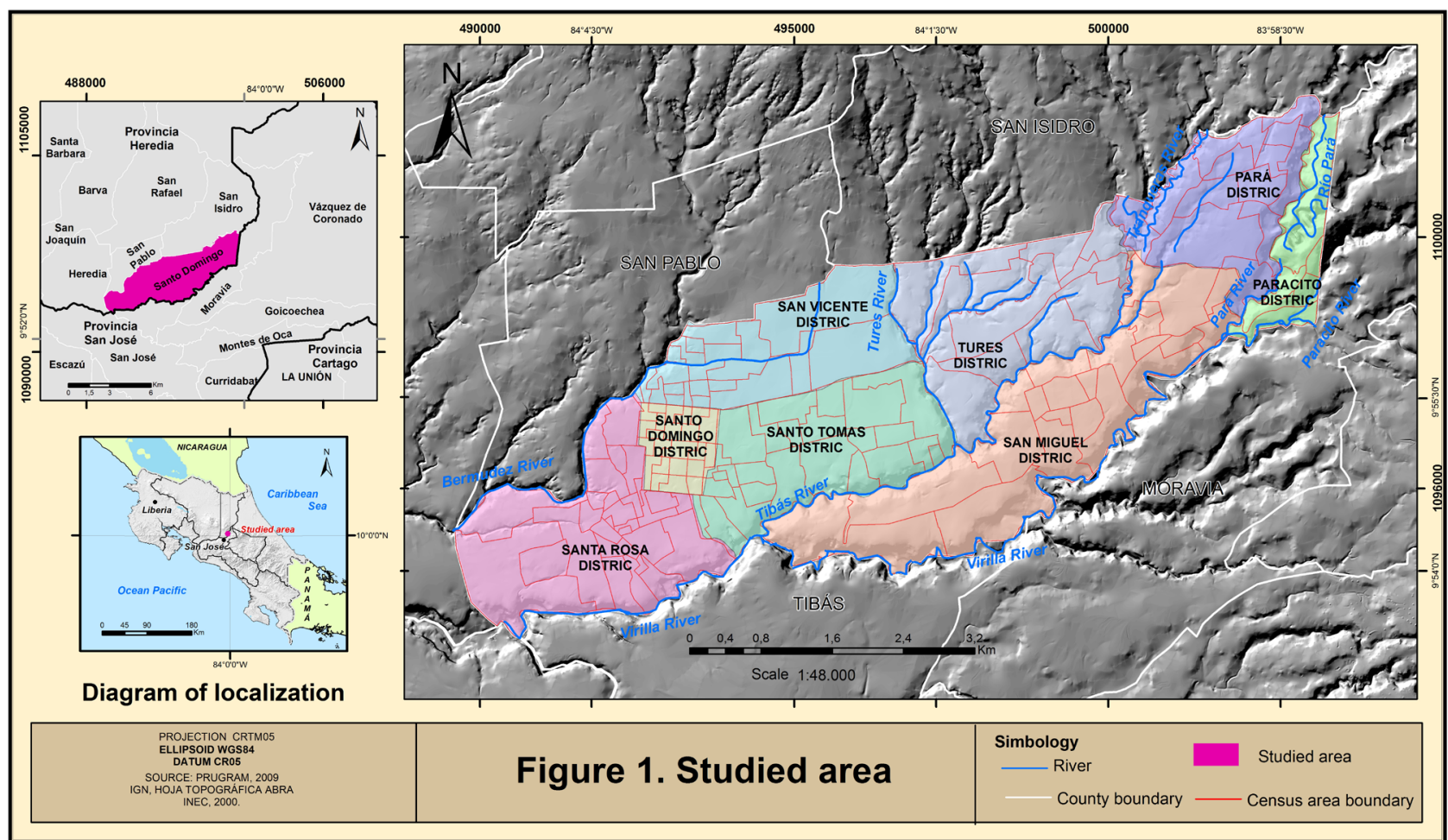

Figure 1. The county of Santo Domingo and its 140 census units (small areas in which districts of Costa Rica are divided). The average size of the census units, measured in number of homes, is defined by the Instituto Nacional de Estadística y Censo (INEC) depending on the work that an interviewer can do to collect census information during a week (60 houses in the urban area and 40 in rural áreas).

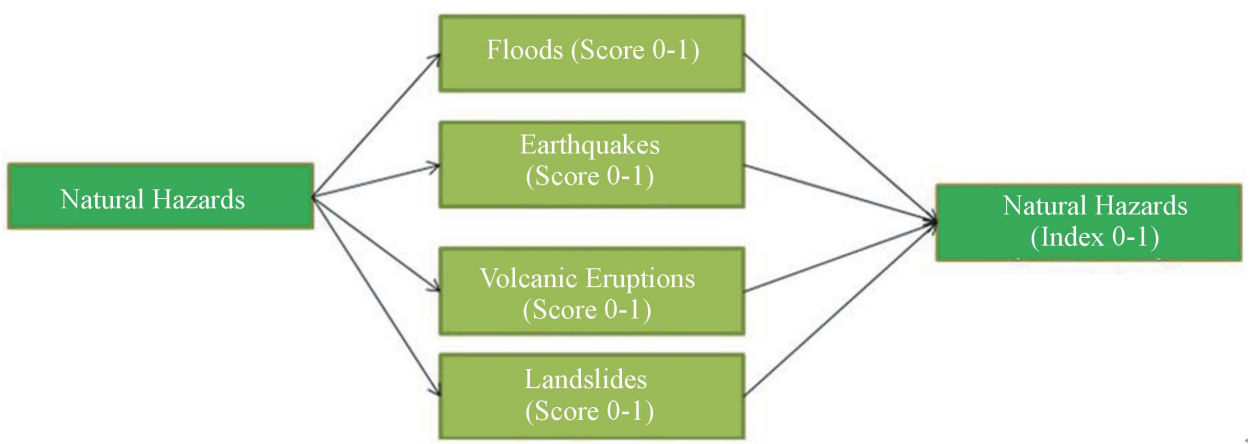

Figure 2. Diagram showing the method for creating the global hazard map for Santo Domingo.

Domingo were downscaled from national-level sources for integration in this analysis [3-6]. Field reconnaissance was used to ground truth the natural hazards maps for Santo Domingo. Then, a density score for each hazard was calculated for each census unit, based on the geographic coverage of the hazard in the unit. For example, if the unit was completely covered by the hazard, it received a score of 1 ; if the unit was $50 \%$ covered, it received a score of 0.50 . We summed the resulting scores for each hazard and divided by the maximum value to obtain a global index of hazard density that ranged from 0 and 1 . We then mapped these values at the level of the census units to create a global map of hazards for Santo
Domingo.

\section{IDENTIFIED HAZARDS}

\subsection{Floods}

The Santo Domingo canton is at serious risk to flooding and has experienced many serious floods over the past two decades. For example, on September 20, 1999, the Río Bermúdez overran its banks and caused a significant flood in the low-lying cities of La Rinconada, Rincón de Ricardo and Barrio Fátima (Figure 3). The water level reached $6 \mathrm{~m}$ above base flow and at least 74 families were seriously affected. The National Emer- 


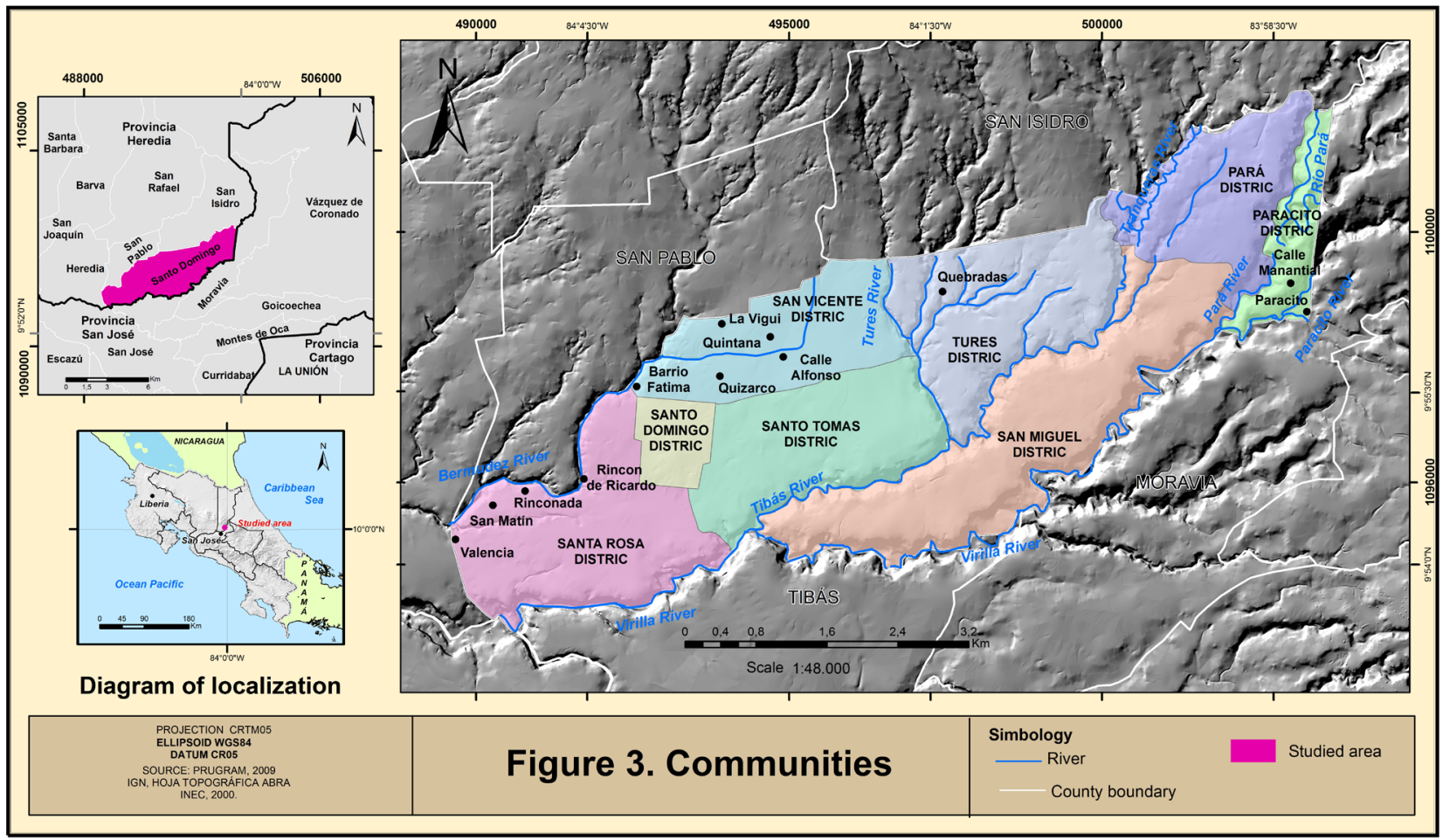

Figure 3. Communities affected by floods in Santo Domingo (black circles). The most damaged communities are located along the Bermudez River.

gency Commission recommended urgent relocation for most of the affected households [7]. In Barrio Fatima alone, 35 families were flooded out and 19 of them were recommended for urgent relocation [8]. As a consequence of this flood disaster, most of the affected families were relocated from the flood zone.

Another severe flood occurred on the evening of November 12, 2007. One of the hardest hit areas was Barrio Fatima, where high waters forced some residents to leave their homes and take refuge in nearby and relatively safe houses and a communal shelter. For the second time, the reports from this emergency included warnings about the need to resettle affected families [9].

Arguably the most severe flood to ever occur in the county took place on July 20, 2010 when the Bermúdez River again overflowed due to prolonged torrential downpours. The affected communities were Rincón de Ricardo, Barrio Fátima, La Rinconada and La Vigui (Figure 4). Reports from the flood detail significant damage in the area. The Local Emergency Committee reported that 22 houses were completely destroyed and that 26 homes were declared uninhabitable [10]. In Barrio Fatima, the municipality reported that 46 families were affected and 38 homes were declared uninhabitable by the Ministry of Health in Santo Domingo [11]. As a result of this disaster, authorities at the Ministry of Health advocated for the relocation of families at-risk to future floods, not permitting development in the area and eventually reforesting the flooded areas.

Flooding issues in the community Rincón de Ricardo along the Bermúdez River are aggravated by construction in the river flood plain and disposing of trash into the river. Trash is especially hazardous in this community because it builds up on the arched bridges from the 1940s, contributing to flooding. For example, during the great flood of 2010, water surpassed the height of a bridge, estimated at 9.32 meters.

Another district where floods are prevalent is Paracito, specifically in the street Calle Manantial, which runs along a natural spring toward the center of town. Water from the spring is shared between Santo Domingo and another county, Moravia (not shown), which gets most of its water from the spring. During high-intensity rains, the flood water combines with the spring to overwhelm the sewage capacity of the system and the water runs over the street, causing flooding in the central area of Paracito.

In addition to the areas already highlighted, there are other places in the county of Santo Domingo where there are more localized situations of flood risk, such as the central area of the District of Santa Rosa, the southern part of the district of San Miguel, Calle Alfonso (a short street that connects La Quintana with Quizarco), Pará (district), and San Martin. In San Martin, a flood caused the destruction of 5 homes in 2010 (Marvin Ocampo, personal communication, 2012). A natural channel runs 


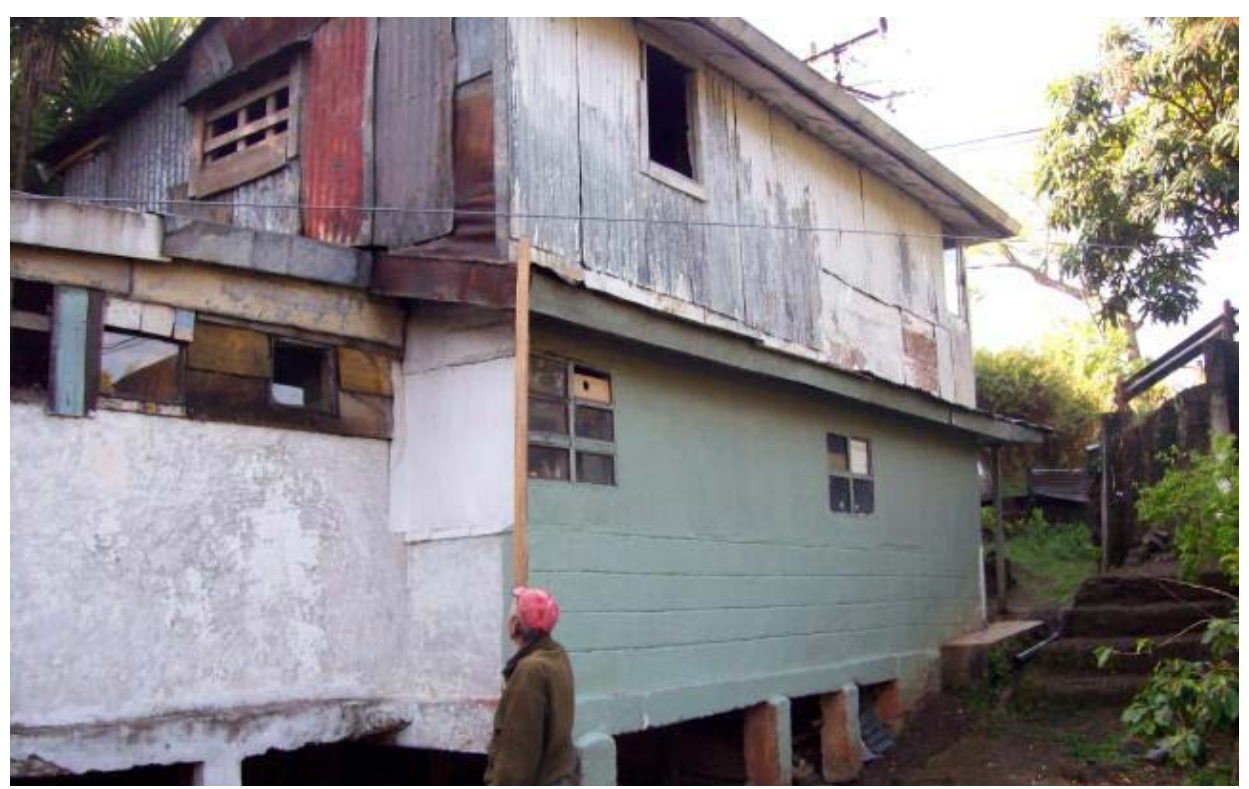

Figure 4. Flooded area in Rincón de Ricardo. Local resident Helio Fonseca shows the level reached by the water during the flood of July 2010.

alongside Calle Alfonso and the water volume in the channel increases significantly during high precipitation events, generating small floods in the nearby Quizarco neighborhood. It is important to highlight that the channel was used in the past to transfer water from San Isidro de Heredia (not shown) to the district of Santo Tomás to be used in coffee plantations. In the District of Pará, there also are floods associated with the Tibás and Pará rivers, but they are not as dangerous as those generated by the Bermúdez River, possibly because of the low density of homes surrounding those rivers.

\subsection{Earthquakes}

Santo Domingo is at high risk for earthquakes, given the several fault lines surrounding the county. Santo Domingo's seismic threat is derived from the faults near Bajo la Hondura, San Jose, and the Poas volcano (Figure 5). The area under the Bajo la Hondura is basically a zone of short normal faults $(<20 \mathrm{~km})$ striking northwest. The Hondura fault is a normal one, while the Lara fault, directly east of the county, is of the strike-slip type. The Angel fault is located in the foothills of the Poas Volcano and was responsible for generating the 6.2 magnitude Cinchona earthquake in 2009. The Alajuela fault passes through the basement of the Central Valley and is a reverse fault that stretches from Grecia to near Heredia.

The most important faults southward of Santo Domingo are Aguacaliente, Escazu, and Aserrí. Each has the potential to generate earthquake damage to Santo Domingo. The Aguacaliente fault presents evidence of normal displacement [12] and is considered responsible for the Cartago earthquakes of 1841 and 1910. The Aserrí-
Escazu fault system stretches for $30 \mathrm{~km}$ and according to [13], combines dextral and lifting displacement and consists of discontinuous fault traces.

Earthquakes of magnitudes close to 6 degrees have originated in the seismic areas surrounding Santo Domingo County. These include the great 1910 Cartago Earthquake, the 1924 Quepos earthquake (not shown), and the recent 2009 Cinchona Earthquake. The Cartago earthquake caused significant damage to Santo Domingo [14]. A 1924 earthquake, which occurred along the Pacific coast, destroyed the tower of the main church of Santo Domingo [15]. The 2009 Cinchona earthquake caused cracks that compromised the integrity of some structures in Santo Domingo [16].

The likelihood of significant damage and injury from earthquakes in the study area is significant due to its physical geography. Because future earthquakes would be generated from faults and subduction zones, Santo Domingo would be exposed to high soil particle accelerations. The accelerations would likely vary from 501 to 600 gals [5], which according to [17], correspond to seismic intensities of between VIII and IX degrees on the Modified Mercalli scale. Values of these intensities correspond to following effects: general panic, destruction of low to medium quality construction, general damage to the foundations and frameworks of buildings, serious damage to dams and underground pipes, and visible cracks in the ground.

\subsection{Volcanic Hazard}

Ash fall from volcanic eruptions is a serious concern in Santo Domingo. Based on topographic maps $(1: 50,000)$, 


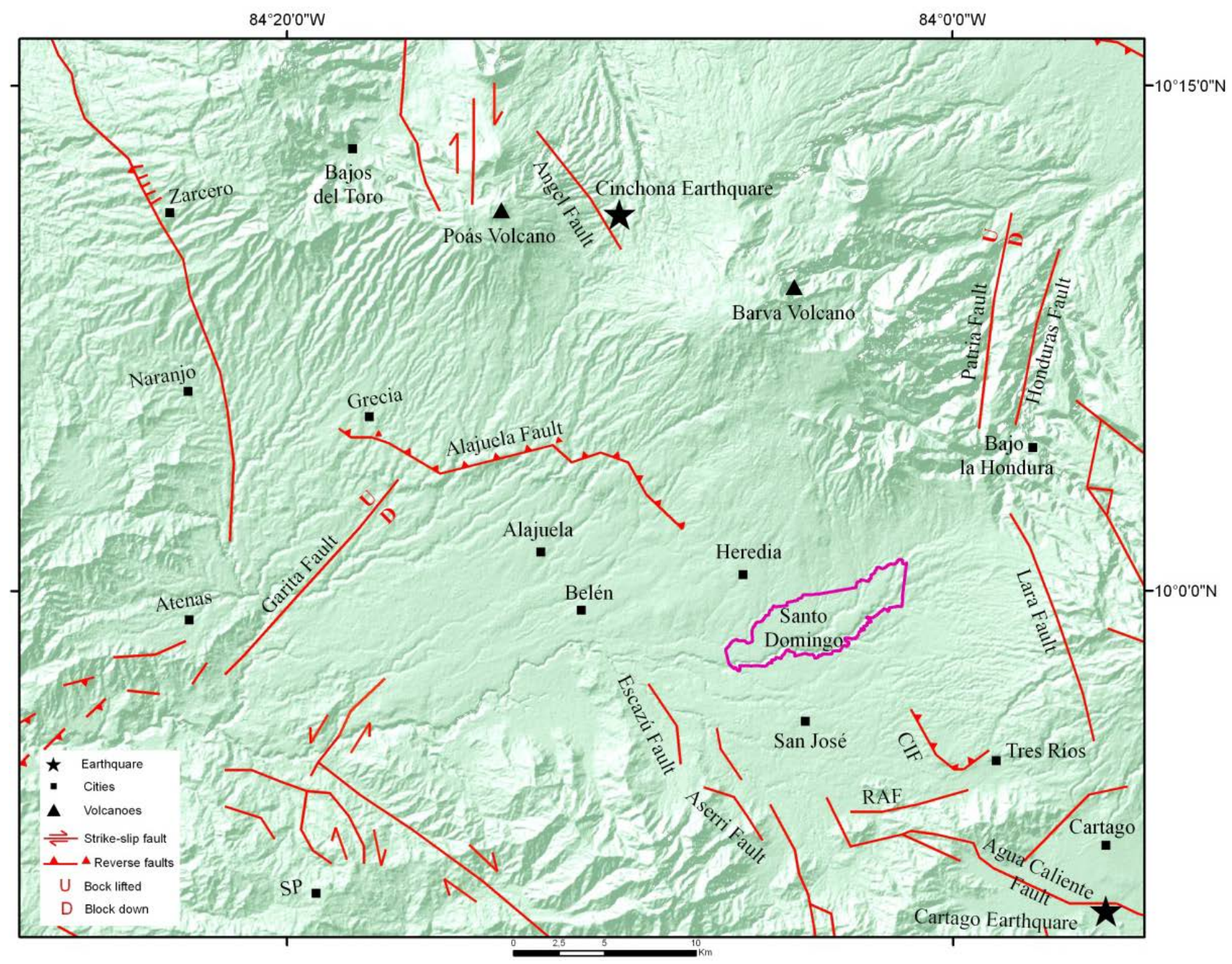

Figure 5. Faults of interest for Santo Domingo. The Alajuela, Angel, Hondura, Lara, Aguacaliente, Escazú, and Aserrí faults could generate moderate magnitude earthquakes with destructive potential in the county. Epicenters of the Cartago 1910 and Cinchona 2009 earthquakes are shown as black stars.

aerial photographs, field research results and geomorphological and geological maps, [4] recognized the potential for volcanic dangers associated with the Cordillera Central of Costa Rica. According to the study, the county of Santo Domingo could be affected by ash fall emitted from the Irazu volcano. Ash particles could contaminate surrounding agricultural fields, negatively impacting production and livelihoods of some families. Fine ash is a trigger for asthma attacks and it could also cause new respiratory problems in the population. Additionally, ash and toxic gases from volcanoes could contaminate drinking water and grazing pastures of domestic animals, leading to serious illness or even death. The most disruptive damage caused by volcanic ash may be the malfunction of cars and technology such as computers, which could interrupt trade, industrial operations, and other human activities.

According to [3], 322,000 years ago there was a vol- canic eruption of great magnitude near Santo Domingo county (Figure 6), which was associated with the Barva caldera, within which is the current Barva volcano. The eruption was violent and produced a pyroclastic flow that spread more than $80 \mathrm{~km}$, from the vicinity of the current Barva volcano to beyond the city of Orotina. Associated deposits from the volcano are up to 80 meters deep in some places, mainly near the Barva volcano. As shown in Figure 6, the current territory of Santo Domingo was severely affected by the event, having been covered by a layer of material up to 30 meters. If people would have been living there at the time, the consequences would have been tragic. The deposit was left by a single flow, not by a series of flows that would have been more manageable, which would have made it particularly devastating. This type of volcanic activity represents a serious hazard for the population of central Costa Rica [3], which includes residents of Santo Domingo. 


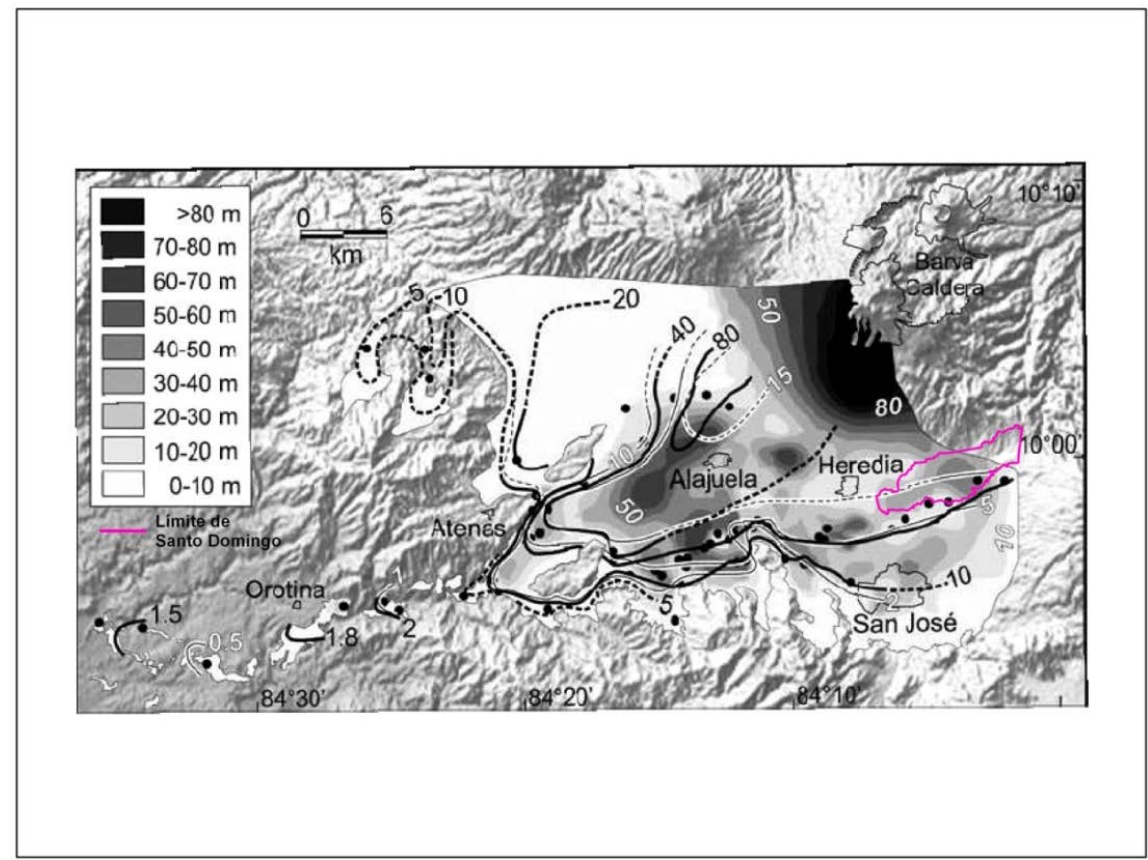

Figure 6. Map showing the area covered by the deposits of the 322,000 year ago Barva volcano eruption. Santo Domingo is the zone affected by such eruption. Grayscale indicates the thickness of volcanic deposits ranges from 10 meters and the contours of black color and black and white are isopleths, i.e., lines of equal size of fragments; black lines refer to juvenile fragments and the black and white are isopleths of lithic fragments that follow a pattern similar to the of juvenile fragments. Black filled circles are the sites where fragments were sampled (adapted from [3]).

\subsection{Landslides}

River canyons in the study area are prone to landslides. Landslides, like all mass earth movements, involve the down slope movement of materials, under the influence of gravity; they can be triggered by rains, earthquakes and human activity [2]. In the county of Santo Domingo, the river canyons associated with the Virilla, Tibás, Bermúdez, Pará and Paracito rivers are especially at risk. Figure 7 shows a deadly landslide from July 2008. After an intense rain, this landslide carried two cars to the bottom of the river, killing one person.

Our analysis reveals that areas requiring attention due to the high risk of landslides and significant population densities include the local communities of Barrio Fatima and Monte Carmelo (near Fatima, not shown) and an unnamed community located at San Miguel Sur road on the way to Los Angeles. Another area which is susceptible to landslides is La Presa in the district of Parasito.

\subsection{Spatial Distribution of Hazards in Santo Domingo}

Based on the data for seismicity, volcanic activity, landslides, and flooding we made a map with the spatial distribution of hazards in the county of Santo Domingo (Figure 8). Each biophysical variable was intersected

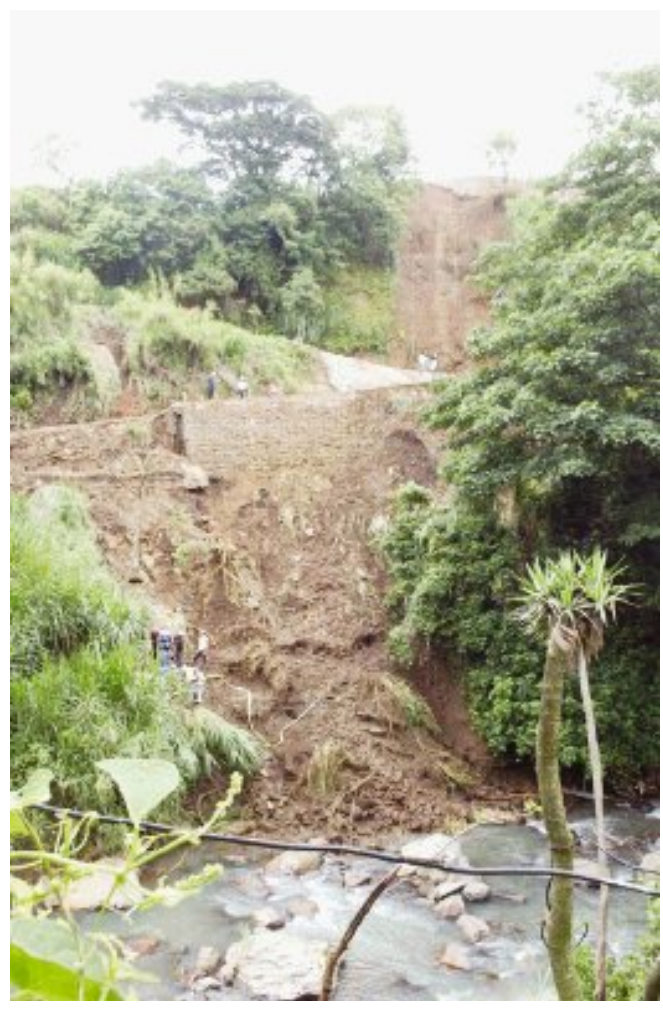

Figure 7. The deadly landslide of July 2008. Courtesy of Periódico Aldía. 


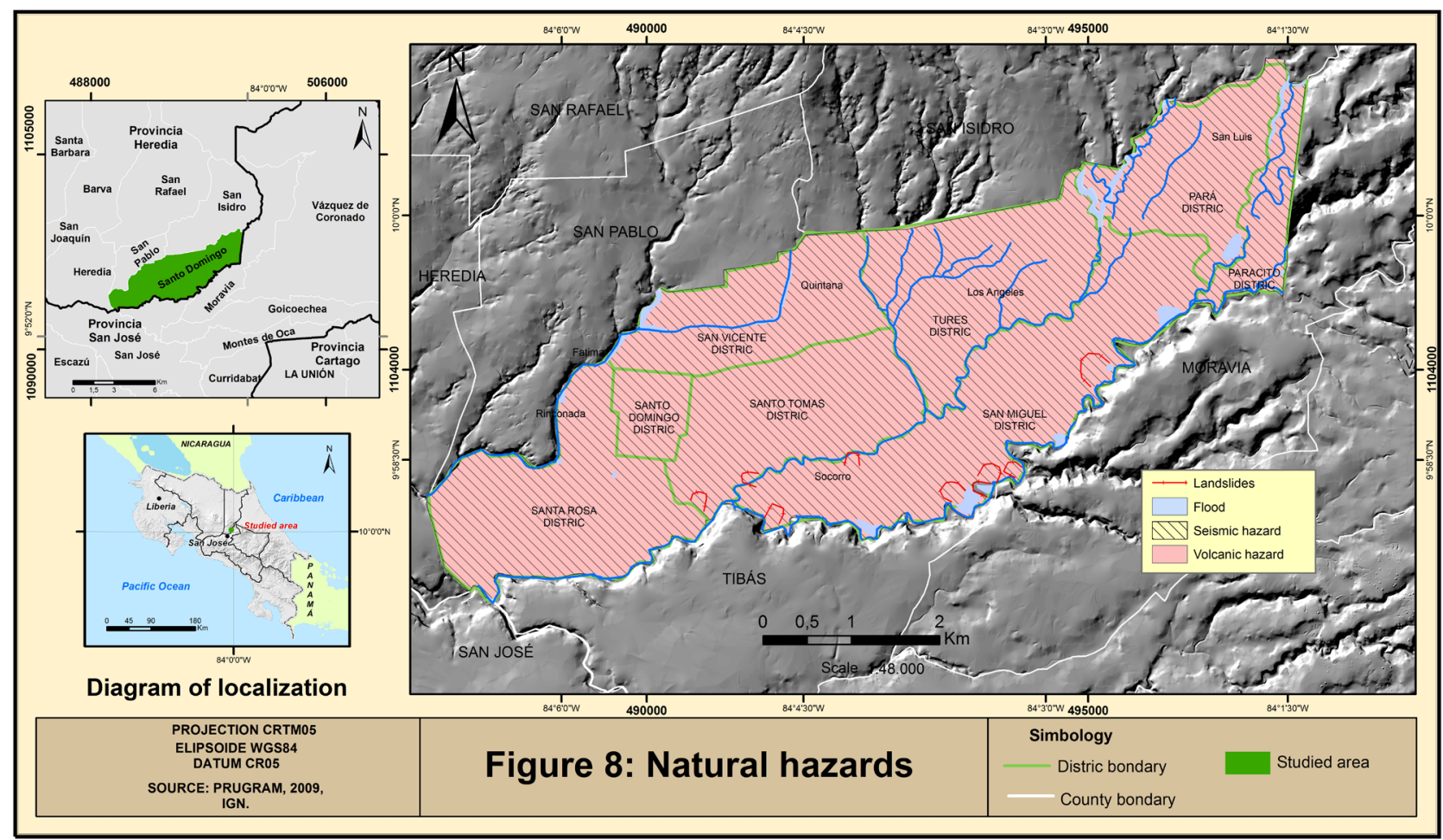

Figure 8. Natural hazards of Santo Domingo.

with the layer of census unit in order to obtain the density of natural hazards by area. Figure 8 shows the distribution of hazards in the zone. It can be observed in the map that both the seismic and volcanic hazards span over the entire area of Santo Domingo.

The longitudinal area along the canyon of the Virilla River presents the highest hazard in the county, while places between the rivers have minor threat because they are in the topographic plateau and therefore are relatively flat. As can be observed from the map, the southern part of the county has the main concentration of hazards. The northern part has a lower density of hazards.

Figure 9 shows the natural hazard density index for Santo Domingo de Heredia, which integrates each of the four hazards (with equal weighting) into one hazard score at the level of the census unit. While flooding and landslide risk are spatially variable, all census units within Santo Domingo are at risk from seismic and volcanic hazards. The map shows that the central part of the county has generally low hazard density. This is because it is flat and only affected by earthquakes and relatively low-impact volcanic activity. Along the northern and southern bounds of the county, the hazard density index increases to medium due to the possibility of flooding in these areas. The areas with the highest density of hazards are also on the edges of the county, mainly in the South. These areas are close to river canyons with the risk of flooding and landslides. There are some "high risk" places like, La Quintana in the north and Santa Rosa in the west, that are relatively flat and not in river canyons; in these areas it is damaged or inefficient sewage systems that put them at risk of significant flooding during high rainfall events.

\section{LIMITATIONS AND FUTURE WORK}

One limitation of this approach is that all four hazards received the same weight in the index. In future work, we will seek to assign a different weight to each individual hazard to more accurately depict the potential impact of each one. A second limitation is that we have neglected technological hazards [18]. We plan to combine those data with the natural hazards identified here to further refine an integrated hazard density index map for Santo Domingo that will better serve the needs of disaster preparedness planning officials in the county. Third, this analysis focuses only on biophysical hazards, which neglects the social vulnerability of residents. Future studies should integrate considerations of social vulnerability with measurement of hazard to better understand risk $[1,19]$. Fourth, the project took place in only one of Costa Rica's 81 cantons, meaning that the 80 remaining counties still need risk assessment mapping; future projects must address needs across the country.

Subsequently, the information will be shared with groups and committees in Santo Domingo working on disaster risk management. Currently, the county is in the 


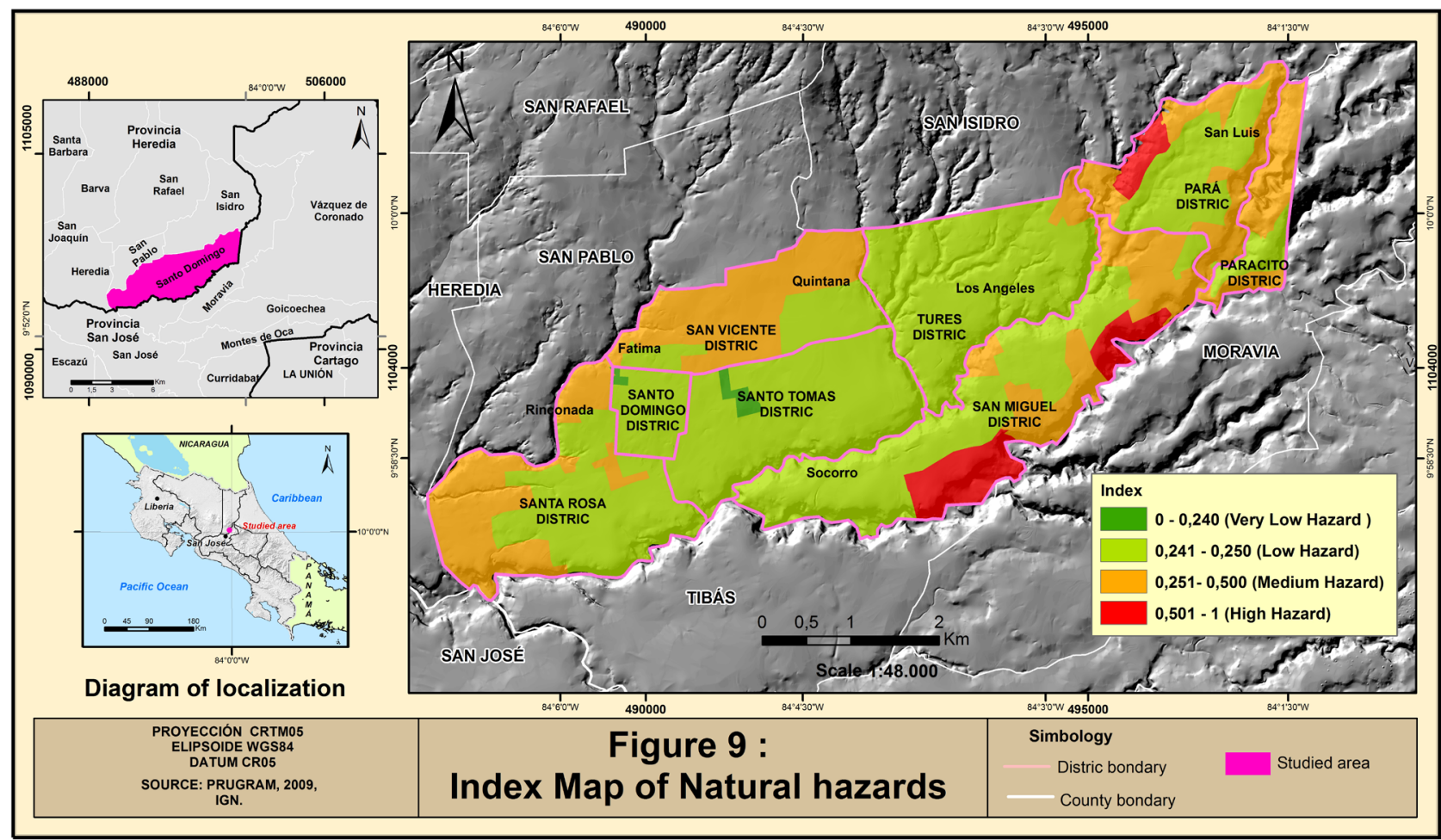

Figure 9. Spatial distribution of natural hazards in Santo Domingo according to the computed density hazard index.

process of forming eight district Emergency Committees, one for each of the county's districts. As such, these results will be disseminated in such a way that results reach all communities in Santo Domingo and members of committees specifically tasked with risk disaster management. In this way, local authorities, who by Costa Rican law must manage disaster risk, will have a spatially explicit guide to relevant hazards in each census unit, which will aid them in complying with national law. This project represents only the first stage in disaster risk management, that is, the identification of risks, which includes both hazards and vulnerability. With these results as a tool, local authorities and risk managers will have to undertake the other two stages, which are risk reduction and the management of emergencies and disasters, which includes prevention, mitigation, immediate response, rehabilitation, and reconstruction.

\section{CONCLUSION AND RECOMMENDATION}

Santo Domingo de Heredia County is affected by at least four natural hazards: flooding, volcanic eruptions, earthquakes and landslides. Of these, flooding has caused the most damage in recent time, as flooding is becoming more frequent and more damaging. In general, the highest density of hazards in Santo Domingo is located in the southern reaches of the county where, besides earthquakes and volcanic activity, risks of flooding and land- slides are also present. Our results provide actionable information to decision makers who work in emergency preparedness and disaster mitigation in the study area. They are the first step toward identifying geographic areas where local authorities should place greater attention on emergency preparedness and disaster mitigation.

\section{REFERENCES}

[1] Collins, T., Grineski, S.E. and Romo, L. (2009) Vulnerability to environmental hazards in the Ciudad Juárez (Mexico)-El Paso (USA) metropolis: A model for spatial risk assessment in transnational contexts. Applied Geography, 29, 448-461. http://dx.doi.org/10.1016/j.apgeog.2008.10.005

[2] Mora, R., Vahrson, W. and Mora, S. (1992) Mapa de amenaza de deslizamientos, Valle Central, Costa Rica. Centro de Coordinación para la Prevención de Desastres Naturales en América Central (CEPREDENAC).

[3] Pérez, W., Alvarado, G. and Gans, P. (2006) The 322 ka Tiribí Tuff: Stratigraphy, geochronology and mechanisms of deposition of the largest and most recent ignimbrite in the Valle Central, Costa Rica. Bulletin of Volcanology, 69, 25-40. http://dx.doi.org/10.1007/s00445-006-0053-x

[4] Paniagua, S. and Soto, G. (1988) Peligros volcánicos en el Valle Central de Costa Rica. Ciencia y Tecnología, 12, 145-156.

[5] Benito, M., Lindholm, C., Camacho, E., Climent, A. Marroquin, G., Molina, E., Rojas, W., Escobar, J., Talavera, E., Alvarado, G. and Tomas, Y. (2012) A new evaluation 
of seismic hazard for the Central America Region. Bulletin of the Seismological Society of America, 102, 504523. http://dx.doi.org/10.1785/0120110015

[6] Fernández, M. (2013) Seismotectonic and the hipothetical strike-slip tectonic boundary of Central Costa Rica. In: D’Amico, S., Ed., Earthquake Research and AnalysisNew Advance in Seismology, INTECH, Croatia. http://dx.doi.org/10.5772/54989

[7] Esquivel, L. (1999) Daños ocasionados por inundaciones en los cantones San Pablo y Santo Domingo de Heredia el pasado 20 de setiembre. CNE, Heredia.

[8] Bolaños, M. (2010) Antecedentes de la situación de riesgo y emergencias en Barrio Fátima, San Vicente de Santo Domingo de Heredia. Dirección de Área Rectora de Salud Santo Domingo de Heredia, Heredia.

[9] Fernández, M., Borges, J., Melendez, G., Mora, F., Mora, J. and Muñoz, C. (2013) Análisis de gestión de riesgo de inundación en la Ciudad de Santo Domingo de Heredia. In: Adamson, M. and Castillo, F., Eds., Costa Rica en el Tercer Milenio: Desafíos y Propuestas para la Reducción de Vulnerabilidad ante los Desastres, San José.

[10] Comité Local de Prevención y Atención de Emergencias de Santo Domingo de Heredia (2010) Evento inundaciones. Informe Tecnico, CNE, Heredia.

[11] Bolaños, R. (2010) Informe general de la emergencia del martes 20 de julio del 2010, acontecido en el cantón Santo Domingo. Informe Técnico, Alcaldía Municipal,
Heredia.

[12] Woodward-Clyde (1993) A preliminary evaluation of earthquake and volcanic hazards significant to the major populations centers of the Valle Central, Costa Rica. Final Report Prepared for Ret Corporation, San José.

[13] Fernández, M. and Montero, W. (2002) Fallamiento y sismicidad del área entre Cartago y San José, Valle Central de Costa Rica. Revista Geológica de América Central, 26, 25-37.

[14] León, F. (2013) Basílica de Santo Domingo de Guzmán. Informe Inédito.

[15] Reyes, J., Fernández, M. and Bolaños, R. (2013) La Amenaza sísmica en Santo Domingo de Heredia. Revista de Salud Ocupacional HOY, País, in press.

[16] Comisión Nacional de Emergencias (2009) Sismo 6.2 Richter Inmediaciones de Cinchona-Poasito-Varablanca Provincia de Alajuela-Heredia. Informe de Situación.

[17] Linkimer, L. (2008) Relationship between peak ground acceleration and modified Mercalli intensity in Costa Rica. Revista Geologica de América Central, 38, 81-94.

[18] Reyes, J. and Fernández, M. (2013) Amenazas tecnológicas en Santo Domingo de Heredia. Revista de Salud Ocupacional HOY, País.

[19] Wisner, B., Blaikie, P., Cannon, T. and Davis, I. (2004) At risk: Natural hazards, people's vulnerability and disasters. 2nd Edition, Routledge, London. 